
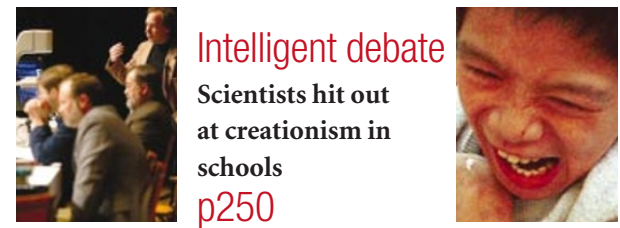

Dioxin damage

US and Vietnam to

cooperate over legacy

of Agent Orange

p252

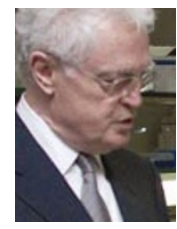

Election promise
French socialist
candidate sets sights
on science
p253

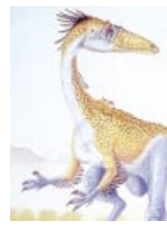

Dead ringer

Joke name for

dinosaur fails to

raise a smile

p254

\title{
Concern mounts as US agencies face challenges to data quality
}

Tony Reichhardt, Washington

US government agencies are scrambling to craft policies that will guarantee the quality of the data they produce, in compliance with a little-noticed law that was passed over a year ago.

The White House Office of Management and Budget $(\mathrm{OMB})$ has given government agencies until 1 May to come up with guidelines for how they will implement the law, which many observers say will make it easier for industry and other affected groups to challenge federal regulations on scientific grounds.

Even though the newlaw (Public Law 106554) does not come into force until October, the industry-backed Center for Regulatory Effectiveness (CRE) has already invoked it. The centre asked the White House science office to stop disseminating the National Climate Assessment, which synthesizes scientific thinking about the consequences of climate change, on the grounds that it relies on "inaccurate" computer models.

The CRE, whose advisory board includes several former OMB officials, helped to draft the data-quality provision of the law, a

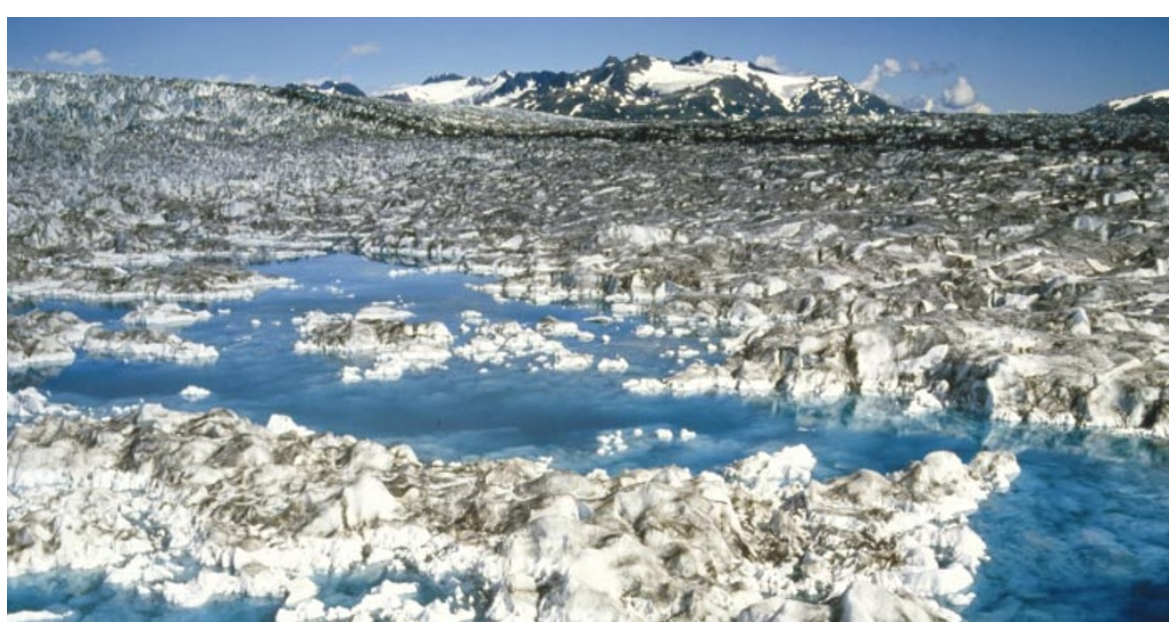

Climate change may be taking its toll in Alaska, but a law could suppress an assessment of its impact.

mammoth spending bill covering many agencies that moved through Congress just before Christmas 2000.

The law directs agencies to find procedures for "ensuring and maximizing the quality, objectivity, utility, and integrity of information" that they disseminate, and to come up with mechanisms allowing "affected persons to seek and obtain correction" of such information where necessary.

A wide range of information published by the government may be affected by the law, including lists of endangered species and research that supports the regulation of pollutants, such as arsenic or airborne soot. All will now have to meet new standards set

\section{Grants for youth aim to revive 'dying' Russian science}

Bryon MacWilliams, Moscow

Russian president Vladimir Putin has responded to mounting complaints about the dire state of the country's science by offering a new grant scheme to young scientists and their supervisors.

In an announcement on 13 March, Putin said that 600 scientists under 35 years of age will receive supplementary grants of 24,000 rubles (US\$770), with their supervisors receiving the same amount. The recipients will be selected through competition.

Putin hopes that the grants will help to slow the exodus of young scientists from Russia, and of young people from Russian science. The average scientist in Russia is now 52 years old, according to government statistics.
Although many researchers have derided the size of the grants - which are nonetheless worth as much as a typical Russian researcher's salary - others have welcomed the fact that Putin has at least acknowledged the problem.

Russian politicians are slowly turning their attention to the collapse of science in the country. For example, Sergei Mironov, speaker of the upper house of the Russian parliament, is backing a budget proposal that would more than double federal funding for science, from less than $2 \%$ of the country's total budget to about $4 \%$.

"If the government doesn't focus attention on the fundamental sciences, they will soon die out," Mironov told an Earth sciences meeting in St Petersburg on 5 March.
Boris Kagarlitsky, a sociologist at the Institute of Comparative Politics in the Russian Academy of Sciences, warns that the new grants could undermine research still further, if they are awarded in lieu of a longterm strategy of investment in research.

And some scientists commenting on Lenta.ru, a discussion website, have derided the grants as insufficient. "The government does not have any money, and should find the strength to admit it," one anonymous correspondent said. "To pompously propose such small grants is hypocritical." However, others said that the grants are better than nothing, and would be helpful to researchers such as mathematicians, theoretical physicists and economists, who do not need expensive equipment. 
by each agency as to what constitutes "quality" research.

In the year since the law was passed, the OMB has published draft guidelines that question whether peer review is, in itself, sufficient to guarantee quality. The OMB originally argued that it was not, citing "cases where flawed science has been published in respected journals".

In some cases, the OMB said, results must be "substantially reproducible" to pass muster. That raised eyebrows in some quarters, such as the National Academy of Sciences, whose president Bruce Alberts wrote in a public comment that reproducibility sets a "new and unreasonable standard" for disseminating scientific information.

The OMB backed off, but not entirely: "It is not OMB's intent that each agency must reproduce each analytic result before it is disseminated," the agency said in its final guidelines last month. But the data and methods used should be transparent enough for someone else to reproduce them.

Researchers fear that the law will be used unscrupulously by opponents of regulation to challenge findings, in disciplines such as climate or ecology, that may be difficult to replicate independently, as in cases where the opportunity to collect fresh data has passed.

Each agency is responsible for coming up with its own procedures for guaranteeing data quality and handling complaints. Jim Tozzi, a Washington-based regulatory consultant and CRE adviser, who signed the letter requesting the withdrawal of the National Climate Assessment, thinks the burden of proof will be on challengers.

"You have to have real data" to make a challenge, Tozzi says. But he predicts that if petitioners are not satisfied by an agency's response, disputes will end up in the courts.

Most federal agencies are still feeling their way to understanding the full implications of the law, according to Tozzi and others. The Environmental Protection Agency declined to comment on how it would draft its policies, and the White House science office, which received the CRE's complaint about the National Climate Assessment, says it is referring the matter to White House lawyers.

But at the Environmental Protection Agency and elsewhere, the level of concern is rising as the May deadline nears. The agency is inviting public comments online on the subject this week, when the National Academy of Sciences will also hold the first of a series of workshops on the law's implications.

www.whitehouse.gov/omb/fedreg/

reproducible.htm

\section{Evolution critics seek role for unseen hand in education}

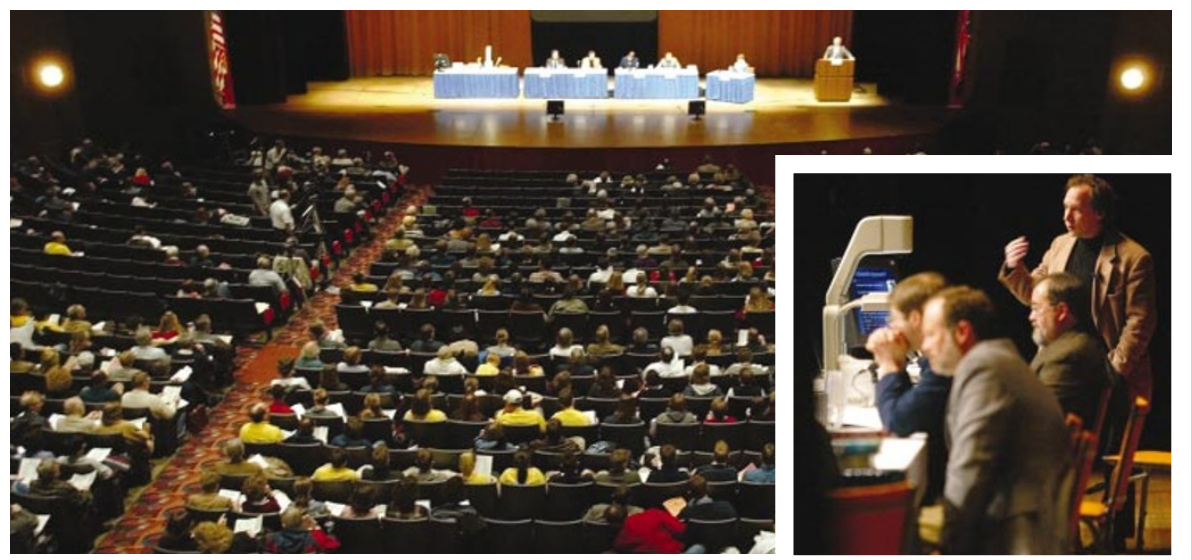

Creative thought: advocates and critics of 'intelligent design' cross swords in Columbus, Ohio.

Trisha Gura, Cleveland

The great debate on teaching evolution and creationism in American schools is back this time with an added twist.

The Ohio State Board of Education is being pressed to instruct teachers in the mid-western state to include 'intelligent design' in their biology lessons, as a possible alternative to Darwin's theory of evolution.

Proponents of 'intelligent design' concede that evolution takes place, but argue that its outcome is too complex to have occurred by chance and so must have been designed by some unseen hand. They told a rowdy public hearing of the board in Columbus on 11 March that including the topic in the school curriculum would help students to understand that scientific theories are always open to challenge.

But many scientists regard intelligent design' as pseudoscience, and say that it is being used as a Trojan Horse to introduce the teaching of creationism into schools.

On the other side of the Atlantic, meanwhile, scientists were protesting because of reports that Emmanuel College in Gateshead - a Christian-run technical college near Newcastle upon Tyne - is indoctrinating its students with creationist ideas. Richard Dawkins, an evolutionary biologist at the University of Oxford, accused the college of teaching "ludicrous falsehoods" and called on the government's education department to investigate further.

In the United States, school curricula are controlled at the state level, and Ohio's education board is revising its standards in response to instructions from Bob Taft, its Republican governor. But at least three members of the 19-person board have taken exception to a draft of the standards, produced in consultation with scientists, because it fails to acknowledge 'intelligent design' as a rival theory to that of evolution.
In response to these concerns, a subcommittee of the board invited two advocates of 'intelligent design' - Stephen Meyer and Jonathan Wells, both fellows of the Discovery Institute, a conservative think tank based in Seattle, Washington - to debate the topic with two of its critics, theoretical physicist Lawrence Krauss of Case Western Reserve University in Cleveland and cell biologist Kenneth Miller of Brown University in Providence, Rhode Island.

Around 1,500 people attended the sometimes-heated debate, in which Wells and Meyer characterized Darwin's theory as being under fire from within the scientific community. Wells waved a list of what he described as 40 peer-reviewed papers criticizing darwinism, and Meyer asked the board to "just permit teachers to teach the evolution controversy".

Krauss said that there was no such controversy. " 'Intelligent design' is an idea," he said. "It is not science, because it does not appear in any peer-reviewed literature." Miller and Krauss both dismissed 'intelligent design' as "creationism dressed up as science".

A subcommittee of the board is due to present standards for science, and other subjects under review, to the full board by September. The board is expected to implement the standards in December - just after elections for six of the board members.

Some observers of Ohio politics say that - with the tacit backing of Taft — the state might implement standards that will open the door to the teaching of 'intelligent design'. Biologists worry that such a move could force the topic into biology textbooks - and open the way for change in Texas, which will discuss its standards next year. "Ohio is just a skirmish," says Miller, a co-author of five biology textbooks. "But it is a rehearsal for what will happen later." 